\title{
Altitudinal genetic variation among native Pinus patula provenances: performance in two locations, seed zone delineation and adaptation to climate change
}

\author{
By L. F. Ruiz-TALONIA ${ }^{1), 2)}$, N. M. SÁNChez-VARGas ${ }^{1)}$, \\ J. S. BAYUELO-JIMÉNEZ ${ }^{1)}$, S. I. LARA-CABrerA ${ }^{3)}$ and C. SÁENZ-Romero ${ }^{\left.1),{ }^{*}\right)}$
}

(Received $10^{\text {th }}$ February 2014)

\begin{abstract}
To select the genetic source of Pinus patula Shiede and Deppe seed best adapted to different native zones for reforestation, seedlings of 12 provenances native to a selected altitudinal gradient in Oaxaca, southern Mexico, were planted on two sites at contrasting altitudes (high $3000 \mathrm{~m}$ above sea level (masl) and low, 2500 masl) within the species natural distribution, and tested for growth in height at age 18, 24 and 36 months. Differences among provenances and between sites showed significance $(p<0.05)$. Seedling growth showed a climatic and altitudinal pattern, in which seedlings from populations originating in low-middle altitudes had higher growth than populations originating in high altitudes, and from the extreme low altitude limit. Results were used to delineate climatic and altitudinal seed zones for contemporary and future climate zones in the decade centered in year 2030, using the average results of six climate-emissions scenarios. The results indicate that splitting the region into four seed zones is appropriate under contemporary climate scenarios with the following altitude limits: Zone 1, from 2300 to 2500 masl; Zone 2,2500 to 2700 masl; Zone 3, 2700 to 2900 masl and Zone 4 from 2900 to 3100 masl. The equivalence on climatic intervals was also defined for mean annual temperature, precipitation and an annual aridity index (AAI). Values of contemporary AAI occurring at a given altitude by year 2030 were determined, with results suggesting that populations should be shifted 200 to 250 $\mathrm{m}$ attitudinally upward, through a program of assisted migration, to realign them to the future climate for which they are adapted.
\end{abstract}

Key words: Assisted migration; climate change; genetic differences; seed zoning; provenances; annual aridity index; Pinus patula.

\footnotetext{
1) Instituto de Investigaciones Agropecuarias y Forestales, Universidad Michoacana de San Nicolás de Hidalgo (IIAFUMSNH), Av. San Juanito Itzícuaro s/n, Col. San Juanito Itzícuaro, Morelia, Michoacán 58330, México.

2) Ecosystem Management, School of Environmental and Rural Sciences, University of New England, Armidale, NSW 2351 Australia.

3) Facultad de Biología, Universidad Michoacana de San Nicolás de Hidalgo, Av. Francisco J. Mújica s/n, Col. Felícitas del Río, Morelia Michoacán 58040, México.

*) Author for correspondence: CuAuHTÉmoc SÁEnz-Romero. Currently at INRA, UMR 1202 BIOGECO, F-33610 Cestas, France \& Univ. Bordeaux, UMR 1202 BIOGECO, F-33615 Pessac, France. Phone: +(52)(443)275-3680 ext. 118 or 117. E-Mail: csaenzromero@gmail.com
}

\section{Introduction}

Pinus patula Shiede and Deppe is an endemic species of Mexico (PerRY, 1991). The species is extensively grown in several countries due to its high growth rates and potential for timber, pulpwood and plywood production (Wright et al., 1995; KARIUKI, 1998; DVORAK et al., 2000).

Ixtlán de Juarez, in the north of the state of Oaxaca, southern México, is an indigenous Zapotec community, in which sustainable forest management and associated industry provides employment for most of the economically active population. P. patula is one of the predominant species used in production and reforestation programs in the north of the state of Oaxaca (OvIEDO, 2002; CASTELlanos-Bolaños et al., 2008; MATSUZAKI and WoNG, 2010).

Provenance tests of forest trees, offer an excellent method for predicting growth changes associated with environmental and climatic change (MATYAS, 1994; Schmidtling, 1994). A multitude of provenance tests set in several countries on pine species show that populations tend to respond differently to selection pressures, in terms of climatic and altitudinal gradients (REHFELDT et al., 2014). Populations at higher altitudes are generally adapted to colder climates, show lower growth potential, shorter periods for shoot elongation and better tolerance to cold environments, compared with those from warmer sites at lower altitudes (WEINSTEIN, 1989; REHFELdT, 1995; SÁENZ-Romero et al., 2012b; CARRASQUINHO and GONÇALVES, 2013). An understanding of the adaptation of tree populations to different environments through accurate site-population matching, together with predicted environmental risks for profitable site and scheduling actions, may enhance decision making and improve reforestation efficiency under both present and future climatic scenarios (Louw and Scholes, 2006; DvoraK et al., 2008; REHFELDT et al., 2014).

There is new evidence that in some mountain habitats climate change is inducing an upward elevation shift of range distribution for some species (PEÑUELAS et al., 2007; LENOIR et al., 2008). However, the speed at which this natural migration is happening might not be enough to keep coupled the tree populations to the climate for which they are adapted (JUMP et al., 2009). Evolutionary processes such as natural migration require time periods that might be longer than the time available, considering the speed at which global warm- 
ing is occurring (AITKEN et al., 2008). Thus, tree populations will likely be decoupled from their ecological niches (REHFELDT et al., 2002; MátyÁs, 2010; MÁTYÁs et al., 2010; SÁenz-Romero et al., 2012a; REHFELDT et al., 2014). It is then necessary for mankind to participate in the adaptation process, and assure that appropriate species and genotypes track their optimum climate in a timely manner, through seed transfer programs from their sites of current location, to places where future optimum climates will occur (SchmidTLING, 1994; TCheBAKova et al., 2006; AitKen et al., 2008). In the present circumstances, this could be done by shifting $P$. patula populations to altitudinal climates for which they will become genetically adapted, taking into consideration the change in altitude and corresponding change in temperature $\left(0.5^{\circ} \mathrm{C}\right)$ with each increase of $100 \mathrm{~m}$ of altitude, that occurs in general in the mountains of Mexico (SÁENZ-ROMERo et al., 2010).

Climatic change is expected to impact the present natural distribution and abundance along latitude and ele-

Table 1. - Geographic location of 13 provenances of Pinus patula collected in the forest of the native Indian community of Ixtlán de Juárez, Oaxaca, México, and the two experimental field sites.

\begin{tabular}{|c|c|c|c|}
\hline Provenance & $\begin{array}{l}\text { Altitude } \\
\text { (m.a.s. 1.) }\end{array}$ & Lat $\mathrm{N}$ & Long $\mathrm{W}$ \\
\hline 1 & 3000 & $17^{\circ} 22.270^{\circ}$ & $96^{\circ 26.987}$ \\
\hline 2 & 2950 & $17^{\circ} 23.154^{\prime}$ & $96^{\circ} 27.402^{\prime}$ \\
\hline 3 & 2900 & $17^{\circ} 23^{\prime} 185^{\prime}$ & $96^{\circ} 27.839^{\circ}$ \\
\hline 4 & 2850 & $17^{\circ} 21.793^{\prime}$ & $96^{\circ} 27.399^{\prime \prime}$ \\
\hline 5 & 2800 & $17^{\circ} 21.795^{\prime}$ & $96^{\circ} 27.562^{\prime}$ \\
\hline 6 & 2750 & $17^{\circ} 23.004$ & $96^{\circ} 28.577^{\prime}$ \\
\hline 7 & 2700 & $17^{\circ} 21.749^{\prime}$ & $96^{\circ} 27.880^{\circ}$ \\
\hline 8 & 2650 & $17^{\circ} 23.162^{\prime}$ & $96^{\circ} 28.938^{\prime}$ \\
\hline 9 & 2600 & $17^{\circ} 23.059^{\circ}$ & $96^{\circ} 28.861^{\prime}$ \\
\hline 10 & 2550 & $17^{\circ} 22.902^{\prime}$ & $96^{\circ} 28.902^{\prime}$ \\
\hline 11 & 2500 & $17^{\circ} 22.808^{\circ}$ & $96^{\circ} 29.067^{\prime}$ \\
\hline 12 & 2450 & $17^{\circ} 22.679^{\prime}$ & $96^{\circ} 28.986^{\circ}$ \\
\hline 13 & 2400 & $17^{\circ} 22.353^{\prime}$ & $96^{\circ} 28.97 l^{\prime}$ \\
\hline
\end{tabular}

Experimental field sites

$\begin{array}{lrrr}\text { Site "Low" } & 2500 & 17^{\circ} 22.480 " & 96^{\circ} 28.580 " \\ \text { Site "High" } & 3000 & 17^{\circ} 23.157 & 96^{\circ} 27.309 \text { " }\end{array}$

vation gradients of $P$. patula, mainly at the margins (VAN ZONNEVELD et al., 2009). According to the projected distribution of suitable climatic habitats for conifers, a complete redistribution of genotypes could be required in order to avoid large losses of forest cover due to climatic change, as has been documented for several forest species (REHFELDT et al., 2002; JOHNSTONE and CHAPIN, 2003; MCLACHLAN et al., 2007; REHFELDT and JAQUISH, 2010; REHFELDT et al., 2012).

In previous provenance testing in a nursery (SÁENZROMERo et al., 2011b) and in growth-chambers similar Pinus patula provenances (SÁENZ-ROMERo et al., 2011a), significant genetic differentiation among populations was evident along an altitudinal gradient.

The objectives of this work were to (1) study the genetic variation for growth traits among populations in field conditions along altitudinal gradients; (2) to delineate zones for seed collection and planting and, (3) to evaluate the potential impact of climate change on the persistence of the natural populations of these species at their contemporary locations, in order to take appropriate conservation action and develop reforestation guidelines.

Our study combined provenances collected along an altitudinal transect, tested at field sites with contrasting altitudes, together with estimated contemporary and future climates for the provenances and test sites, using a climatic spline model. Climate projections considered three General Circulation Models (GCMs) under each of two greenhouse-effect gas emission scenarios, thus aiming to provide a common basic impact and adaptation assessment for climate change.

The results may be used in selecting the appropriate sources for seeds collection and transfer along an altitudinal gradient through reforestation guidelines, by matching genotypes with the appropriate planting site in the forests, in the context of climatic change.

\section{Material and methods \\ Seedling sources and establishment}

Open-pollinated seeds from 13 native $P$. patula populations were collected along their natural altitudinal range of distribution in Ixtlán de Juárez, Oaxaca Mexico - one population every 50 meters of altitudinal difference, from 2400 to 3000 masl, 11 trees per population, randomly identified from the forest as those bearing mature cones. The trees represented by these samples are termed 'populations', while the location of a population is termed 'provenance'. Seed was sown in pots in a randomized block design in a nursery at Ixtlán de Juárez (SÁENZ-Romero et al., 2011b). When seedlings were nine months old with average seedling height of $28 \mathrm{~cm}$, they were transplanted to two locations within the natural forests of Ixtlán de Juárez at contrasting altitudes; one site close to the highest and the other to the lowest natural limits of the species in the area. The 'high site' was located at 3000 altitudinal meters ( $\left.17^{\circ} 23.157^{\prime} \mathrm{LN}, 96^{\circ} 27.309^{\prime} \mathrm{LW}\right)$, and the 'low site' at 2500 altitudinal meters $\left(1^{\circ} 22.480^{\prime} \mathrm{LN}, 96^{\circ} 28.580^{\prime} \mathrm{LW}\right)$ (Table 1, Figure 1). The provenance test was established 


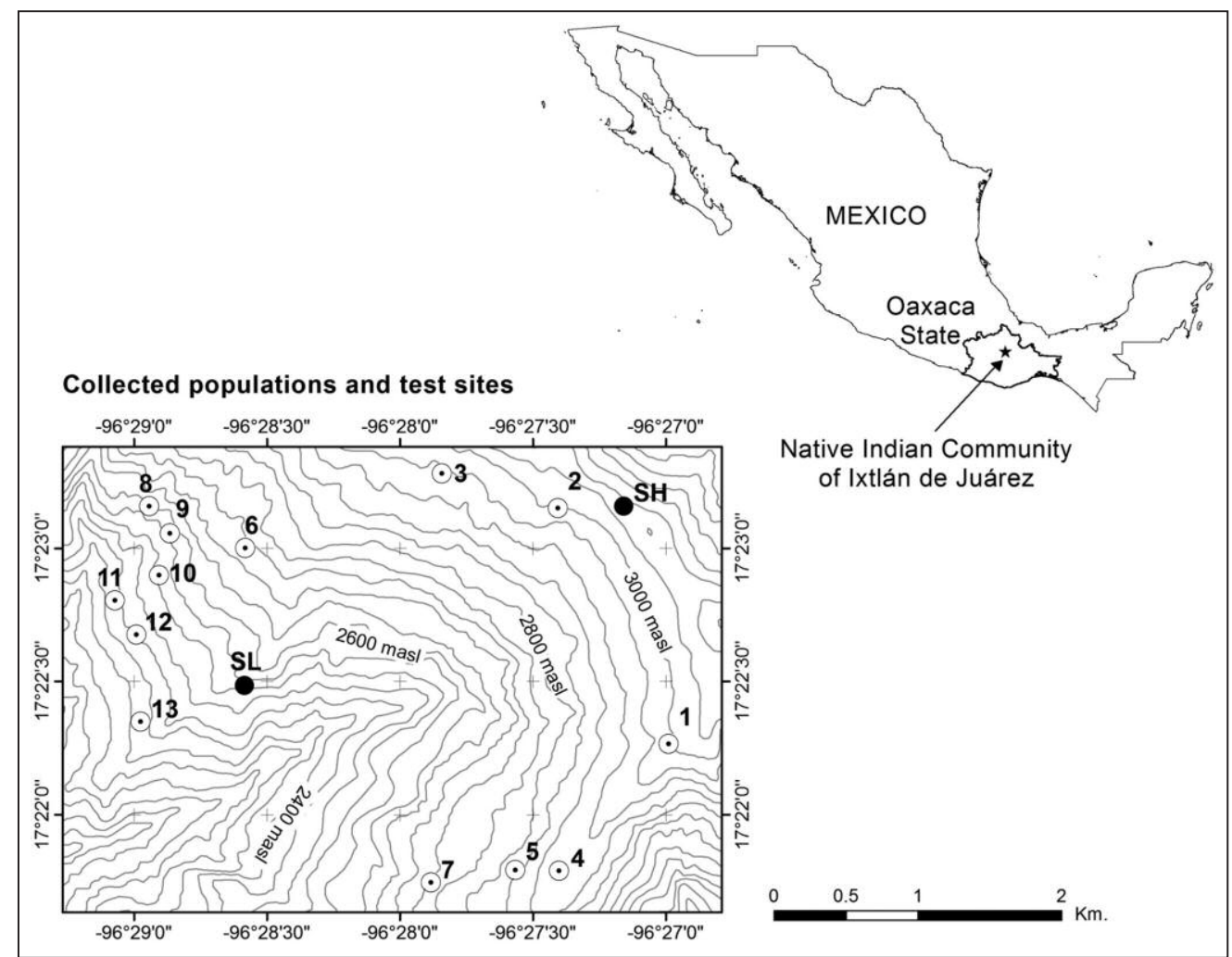

Figure 1. - Geographic location of the collected Pinus patula populations and tests sites in the forest of the native Indian community of Ixtlán de Juárez, Oaxaca, México. Population number in the panel insert as coded in Table 1. SH and SL indicate tests sites at high $(3000 \mathrm{~m})$ and low $(2500 \mathrm{~m})$ altitude, respectively.

in the rainy season (early August) of 2008. Each site had an identical design: randomized complete block design with 12 blocks, 13 provenances and four seedlings per plot in a row (48 seedlings per provenance per field site).

\section{Assessment and data analysis}

Total seedling heights (cm) were measured at 18, 24 and 36 months (age from seed germination), equivalent to 9,15 and 27 months post-planting. The significance of differences among sites and among populations was determined by an analysis of variance using PROC GLM (SAS 2011), and model [1]. Blocks and populations were considered as random effects and site was considered as fixed. We used the option TEST to specify the appropriate denominator for F-statistics. The proportion of variance compared with the total variance was estimated using PROC VARCOMP METHOD = REML (SAS, 2011). It was conducted a mean multiple comparison using Tukey tests, to identify where significant differences existed between population means.

$$
\begin{aligned}
\mathrm{Y}_{i j k l}= & \mu+\mathrm{S}_{i}+\mathrm{P}_{j}+\mathrm{B}_{k}\left(\mathrm{~S}_{i}\right)+ \\
& \mathrm{S}_{i} * \mathrm{P}_{j}+\mathrm{P}_{j} * \mathrm{~B}_{k}\left(\mathrm{~S}_{i}\right)+\mathrm{e}_{i j k l}
\end{aligned}
$$

Where $\mathrm{Y}_{i j k l}$ is the individual-tree observation, $\mu$ the overall mean, $\mathrm{S}_{i}$ the effect of the $i^{\text {th }}$ site, $\mathrm{P}_{i}$ the effect of the $j^{\text {th }}$ population, $\mathrm{B}_{k}\left(\mathrm{~S}_{i}\right)$ the effect of the $k^{\text {th }}$ block nested in the $i^{\text {th }}$ site, $\mathrm{S}_{i} * \mathrm{P}_{j}$ the interaction of the $i^{\text {th }}$ site by the $j^{\text {th }}$ population, $\mathrm{P}_{j} * \mathrm{~B}_{k}\left(\mathrm{~S}_{i}\right)$ the interaction of block nested in site by population and $\mathrm{e}_{i j k l}$ is the error term.
An analysis of variance and estimation of the components of variance was conducted for each separate site, using the same model [1], but without the site term and its interaction.

We determined a pattern of altitudinal differentiation through conducting a regression analysis (linear and quadratic) between provenance performance and the climate or altitude of origin, using PROC REG (SAS, 2011).

Simple linear regression:

$\mathrm{Y}_{i j}=\beta_{0}+\beta_{1} \mathrm{X}_{i}+\mathrm{e}_{i j}$

Quadratic regression:

$\mathrm{Y}_{i j}=\beta_{0}+\beta_{1} \mathrm{X}_{i}+\beta_{2} \mathrm{X}_{i}{ }_{i}+\mathrm{e}_{i j}$

Where $\mathrm{Y}_{i j}=$ mean seedling height of the $i^{\text {th }}$ provenance, $\beta_{0}=$ intercept, $\beta_{1}$ and $\beta_{2}=$ regression parameters, $\mathrm{X}_{i}=$ climate or altitude (masl) of the $i^{\text {th }}$ provenance and $\mathrm{e}_{i j}=$ the error.

\section{Climate estimations}

Contemporary climate estimations (average of years 1961-1990) were made for each of the 13 collection sites and the two field test sites with a spline climate model, such as in SÁENZ-ROMERo et al. (2010). It was assumed that contemporary populations are adapted to the contemporary climate and not to the average for 2000-2010, and thus already affected by global warming. 
We estimated for each site mean annual temperature, annual degree days $>5^{\circ} \mathrm{C}$ (DD5), mean annual precipitation (MAP), and an annual aridity index (AAI, ratio of square root of DD5 to MAP). The index indicates the association between the temperature suitable for plant growth (daily temperatures above $5{ }^{\circ} \mathrm{C}$ ), and moisture availability (precipitation) throughout the year. Climate variables were selected on the basis of having demonstrated relevance and association with forest tree population genetic differentiation and performance (REHFELDT, 2006) and association with biome distributions (REHFELDT et al., 2006). Climatic values were obtained by querying a spline climatic model (SÁENZROMERo et al., 2010) uploaded on a web site interface (http://forest.moscowfsl.wsu.edu/climate/; REHFELDT, 2006; CROOKSTON and REHFELDT, 2013), in terms of latitude, longitude and elevation of each collection and field test site.

We selected the decade centered on the year 2030 as the target for realigning the tree populations to the future climate for which they were adapted, to avoid damage from frost on recently planted seedlings; if contemporary genotypes were transferred to higher, colder altitudes where suitable weather is expected to occur by the decade centered in the year 2060 or further, it is likely that severe frost damage could occur in the present, after planting (SÁEnZ-Romero et al., 2012a; LoYAREBOLlar et al., 2013).

Future climate estimates were assessed with the average output data across six climate model-scenarios, being the results from the three global circulation models (GCMs). Each GCM was combined with each of the two greenhouse-effect gas emission scenarios: (1) CGCM3 (T63 resolution), from Canadian Center for Climate Modeling and Analysis (CCCMA), scenarios A2 and B1; (2) HadCM3, from Met Office, Hadley Centre (UKMO), scenarios A2 and B2; and (3) CM2.1, Geophysical Fluid Dynamics Laboratory (GFDL), scenarios A2 and B1.

The A2 emissions scenarios assume in general continued high emissions from an increasing human population, but dissimilar economic and technological development according to country, and are thus regionally oriented, sometimes referred to as the 'business as usual' or 'pessimistic scenario'. Alternatively the B1 and B2 scenarios combine social and economic solutions to sustainability, a lower rate of increase in global population and slower, more diverse technological development with emphasis on environmental protection and social equity, than the A2 scenarios, thus referred to as the 'optimistic scenario' (IPCC, 2013).

Clines were developed to estimate the upward altitudinal shift needed to realign the $P$. patula population to the sites in which they would occur under a future climate (decade centered in the year 2030). Regression models were fitted for a contemporary and future climate variable AAI, adjudged as the single climatic variable best representing the climate, incorporating degree days and precipitation available for plant growth, against the altitude of the provenance of origin, using Proc REG (SAS 2011), to assess climatic clines among populations in genetic responses to climate of provenances.

\section{Seed zoning}

We delineated climatic and altitudinal zones, using the least significant difference (LSD, $\alpha=0.20$ ) among populations of 36 month-old seedling height. The LSD value was translated to the climatic or altitudinal difference that makes two populations statistically different. The regression model fit between population performance against climate or altitude of the population of origin was used to delineate the zones, as well the association between altitude and climate values of the provenances (REHFELDT, 1991; SÁENZ-ROMERO et al., 2006). It is noteworthy that use of 0.2 alpha error on this zone delineation process leads to a more conservative set of management rules, because the resulting altitudinal intervals, making two population significantly different, are narrower and therefore there will be more restrictions on seed movement (SÁENZ-ROMERo et al., 2006; Soto-Correa et al., 2012; CAStellanos-AcuÑa et al., 2014).

\section{Results \\ Differences between test locations and populations}

Evaluations on seedling growth indicate highly significant statistic differences between locations $(\mathrm{P} \leq 0.05)$ at all ages tested. Genotype by environment interactions (site $\mathrm{x}$ population) were also significant. Populations growing at the low site $(2500 \mathrm{~m})$ had, on average, more than twice the seedling height than seedlings at the high altitude site (100 cm vs. $48 \mathrm{~cm}$ at 24 months; and 220 vs. $93 \mathrm{~cm}$ at 36 months old ) (Table 2, Figure 2).

Differences in seedling height among populations were not significant at any age, when the analysis was conducted across both sites using the full statistical model. However, in the separate site analyses, significant statistical differences were identified for mean seedling height among populations, except for the site at high altitude at 36 months of age (Table 2).

The generally poorer growth at the high altitude test site (Figure 2) and the lack of significance among populations at age 36 months (Table 2), might be the result of stress induced by the cold conditions of this site, located at $3000 \mathrm{~m}$ of altitude. Several seedlings exhibited very short needles and dead or damaged leader buds. Damaged terminal buds on such short seedlings in all likelihood increased the variation within the provenance, thus causing a reduction in statistical power to reflect significant differences among populations.

\section{Altitudinal and climatic pattern of genetic differentiation}

Population means for seedling height were significantly different between provenances and related to provenance altitude of origin or provenance climate in the low altitude test site (2500 m; Figure 3a). At the low altitude test site, the best regression fit, for the three ages measured, was obtained by quadratic modeling of seedling height against altitude: $\mathrm{r}^{2}=0.65, \mathrm{P}=0.005$ at 18 months; 
Table 2. - Individual-site and pooled site analyses of variance for 18, 24 and 36 monthold Pinus patula provenance tests. Percentage contribution to total variance (\%) and significance values $(\mathrm{P})$.

\begin{tabular}{|c|c|c|c|c|c|c|}
\hline \multirow[t]{2}{*}{ Source of Variation } & \multicolumn{2}{|c|}{18 months } & \multicolumn{2}{|c|}{24 months } & \multicolumn{2}{|c|}{36 months } \\
\hline & $\%$ & P & $\%$ & $P$ & $\%$ & $P$ \\
\hline \multicolumn{7}{|c|}{ Overall } \\
\hline Site & 51.1 & $<.0001$ & 72.1 & $<.0001$ & 77.9 & $<.0001$ \\
\hline Population & 2.6 & 0.191 & 0.7 & 0.272 & 0.4 & 0.287 \\
\hline Block (Site) & 1.6 & 0.002 & 2.5 & $<.0001$ & 4.0 & $<.0001$ \\
\hline Site * Population & 3.2 & 0.001 & 1.3 & 0.012 & 1.1 & 0.010 \\
\hline P'op Block (Site) & 2.7 & 0.089 & 3.2 & 0.010 & 2.2 & 0.005 \\
\hline Error & 38.7 & & 20.1 & & 14.5 & \\
\hline \multicolumn{7}{|c|}{ Low Sitc 2500 masl } \\
\hline Population & 8.6 & 0.001 & 7.4 & 0.006 & 7.9 & 0.001 \\
\hline Block & 4.5 & 0.008 & 10.7 & $<.0001$ & 24.3 & $<.0001$ \\
\hline l'opulation "s Block & 6.6 & 0.020 & 14.4 & 0.001 & 10.0 & 0.003 \\
\hline Error & 80.4 & & 67.5 & & 57.8 & \\
\hline \multicolumn{7}{|c|}{ High Site 3000 masl } \\
\hline Population & 23.8 & $<.0001$ & 6.5 & 0.002 & 0 & 0.535 \\
\hline Block & 1.2 & 0.321 & 6.6 & 0.001 & 3.0 & 0.026 \\
\hline Population * Block & 5.3 & 0.283 & 0 & 0.713 & 11.7 & 0.061 \\
\hline Error & 69.7 & & 86.9 & & 85.3 & \\
\hline
\end{tabular}

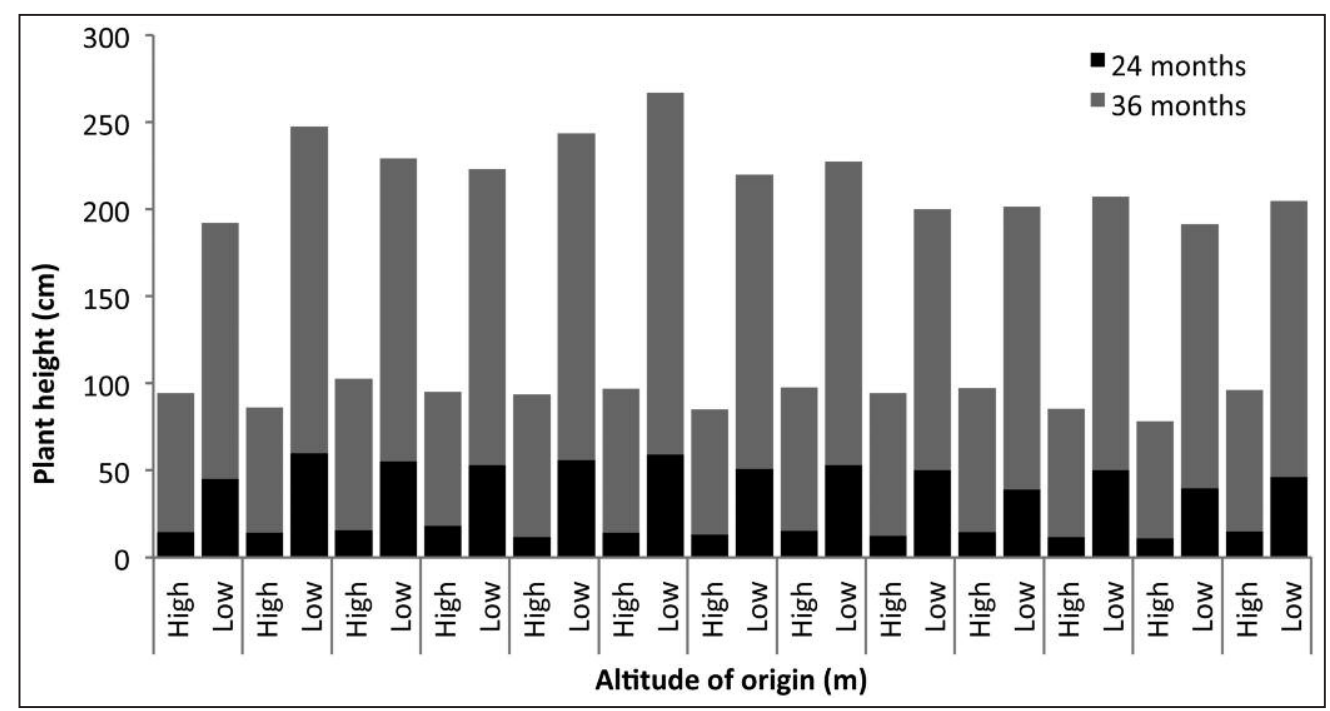

Figure 2. - Average seedling height at age 24 and 36 months for 13 populations of Pinus patula in a provenance test. High $=$ High altitude provenance test site $(3000 \mathrm{~m})$. Low $=$ Low altitude provenance test site $(2500 \mathrm{~m})$.

$\mathrm{r}^{2}=0.56, \mathrm{P}=0.019$ at 24 months and $\mathrm{r}^{2}=0.42 \mathrm{P}=0.067$ at 36 months respectively. In general, populations from low-mid and mid altitudes achieved better growth (Figure $3 a$ ), than populations from the extreme low and high altitudinal limits. This altitudinal trend was similar at the high altitude site (3000 m; Figure $3 b)$, although less pronounced and not significant. At both field sites, the population from altitude $2650 \mathrm{~m}$ (the mid-low part of the altitudinal distribution) demonstrated the best growth by far (Table 2, Figure 3). 
Similar growth trends were found at early ages (6month-old at nursery stage) in the same provenances (SÁENZ-Romero et al., 2011b), as well as in the growth chambers (SÁENZ-ROMERo et al., 2011a).

A very similar and significant clinal pattern was found when regressing average 36-month-old seedling height from the low altitude site, against climate of the provenances, in particular against Annual Aridity Index values: quadratic model: $\mathrm{r}^{2}=0.58 \mathrm{P}=0.019$. In general, populations from high-mid and mid annual aridity index values achieved better growth (Figure $3 a$ ), than populations from the annual aridity index extreme low index values (too cold and humid) and the extreme high index values (too dry and warm). The similarity between altitudinal and climatic patterns for seedling performance are due to the strong association between Annual Aridi- ty Index (AAI) and altitude, indicated by a highly significant regression analysis $\left(\mathrm{r}^{2}=0.98, \mathrm{P}=<.0001\right)$. This strong association can be explained by the strong altitudinal cline of growing degree days $>5^{\circ} \mathrm{C}$. At the high elevation site, however, regressions between climate or altitude of provenance against seedling height average per population, were not statistically significant at any age (Figure $3 b$ ), most likely due to the generally poor growth across populations.

\section{Seed zoning and guidelines for seed movement}

Least significant difference (LSD $\alpha=0.20$ ) among provenances was equal to $18 \mathrm{~cm}$ for seedling total height. When using that LSD value for delimiting the altitudinal or climatic zone interval limits, by finding its equivalence on an altitudinal or climate interval making
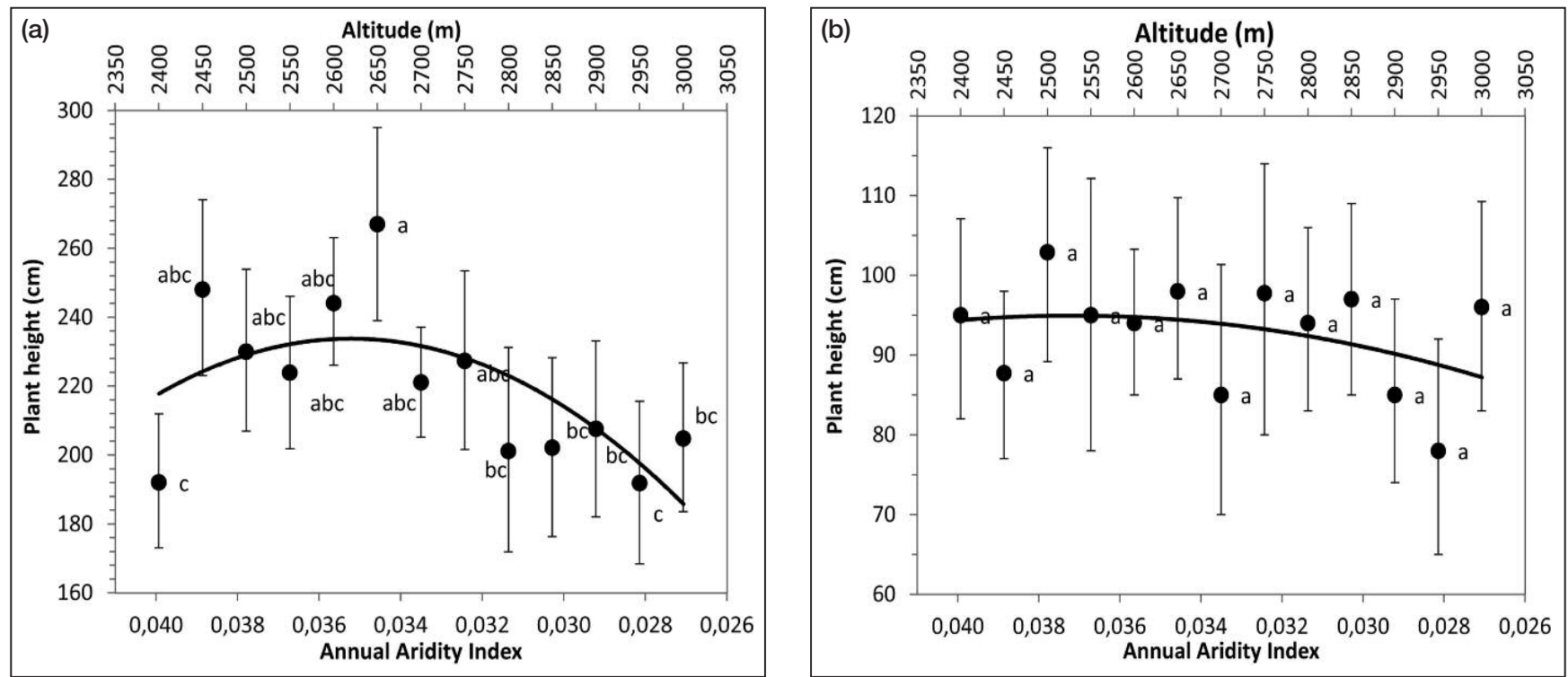

Figure 3. - Regression between average seedling height per population against Annual Aridity Index (AAI; larger index values = warmer and less moisture, more arid; lower values = colder and more moisture, less arid) or altitude (m) of seed source, using a quadratic model (solid line, using all populations). a) Low altitude site $(2500 \mathrm{~m})$. b) High altitude site $(3000 \mathrm{~m})$. Vertical bars indicate population average confidence intervals (95\%). Different letters indicate mean grouping according to Tukey $(\alpha=0.05)$ test.

Table 3. - Proposed altitudinal and climatic limits of the four seed zones of $P$. patula, established for the region of Ixtlán de Juarez, Oaxaca, southern México.

\begin{tabular}{|c|c|c|c|c|c|c|c|c|c|c|c|c|}
\hline \multirow{3}{*}{ Zone } & \multicolumn{3}{|c|}{ Altitude (m) } & $\mathrm{Mc}$ & an Ann & lal & Annu & Precip & tation & Annua & Aridity & Index \\
\hline & \multicolumn{2}{|c|}{ Limits } & \multirow[b]{2}{*}{ Range } & \multicolumn{2}{|c|}{ Limits } & \multirow[b]{2}{*}{ Range } & \multicolumn{2}{|c|}{ Limits } & \multirow[b]{2}{*}{ Range } & \multicolumn{2}{|c|}{ Limits } & \multirow[b]{2}{*}{ Range } \\
\hline & Lower & Upper & & Lower & Upper & & Lower & Upper & & Lower & Lipper & \\
\hline l & 2300 & 2500 & 200 & 14.7 & 13.5 & 1.2 & 1411 & 1499 & 88 & 0.041 & 0.037 & 0.004 \\
\hline 2 & 2500 & 2700 & 200 & 13.5 & 12.3 & 1.2 & 1499 & 1587 & 88 & 0.037 & 0.033 & 0.004 \\
\hline 3 & 2700 & 2900 & 200 & 12.3 & 11.1 & 1.2 & 1587 & 1675 & 88 & 0.033 & 0.029 & 0.004 \\
\hline 4 & 2900 & 3100 & 200 & 11.1 & 9.9 & 1.2 & 1675 & 1763 & 88 & 0.029 & 0.025 & 0.004 \\
\hline
\end{tabular}


any two populations significantly different, we found different interval sizes, due to the quadratic shape of the curve (Figure 4). Zone delimitation commenced in such a manner that one zone could be centered approximately

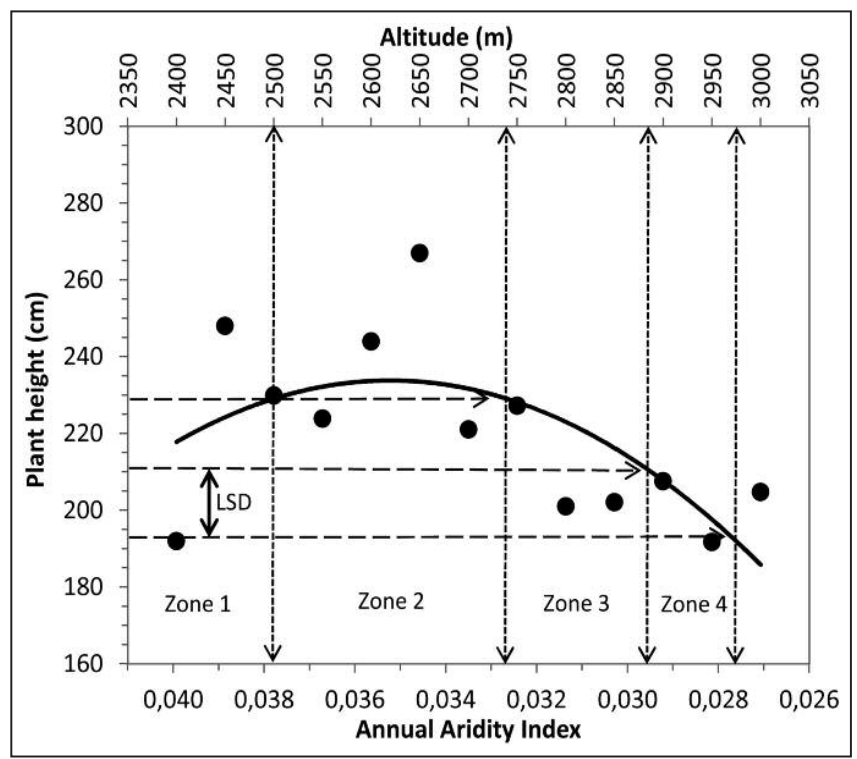

Figure 4. - Delineation of climatic or altitudinal seed zones. The quadratic regression line between average seedling height per population against Annual Aridity Index of seed source is intersected by an interval whose width is defined by seedling height least significant difference (LSD, indicated by the double solid arrow) that makes two populations genetically different. The associated vertical broken lines (double arrows) show the equivalence of such difference on the $\mathrm{Y}$ axis, either for annual aridity index or (approximately) for altitude (m). on those populations with the best growth (population from $2650 \mathrm{~m}$ of altitude), and was then continued the towards the downward and upward altitudinal cline. The resulting climatic or altitudinal zones were named Zone 1 , with a width of 0.0030 of annual aridity index value (AAI) or $150 \mathrm{~m}$ of altitudinal difference; Zone 2, the one centered at the best populations, with a width of 0.0045 of AAI or $240 \mathrm{~m}$; Zone 3: 0.0040 AAI or $135 \mathrm{~m}$; Zone 4: 0.0020 or $90 \mathrm{~m}$ (Figure 4). However, seed zones should not only be scientifically sound, but also practical for management (SÁENZ-ROMERo et al., 2006). In the present case, zone 4 undoubtedly is too narrow to be useful for management purposes. Consequently, we suggest the use of a fixed zone of $200 \mathrm{~m}$ width in altitudinal difference - the average width across zones was $154 \mathrm{~m}$, with the centered zone $240 \mathrm{~m}$, which is approximately equivalent to 0.004 units of AAI. Further, maintaining the practice of centering one seed zone on the best performing populations, we suggest a seed zone delimitation as demonstrated in Table 3, which for practical management of seed zones, can be converted from contemporary climate variables to altitude, or vice versa, due to the significant association, as mentioned above, between altitude and Annual Aridity Index. Seed zone delimitation based on AAI, mean annual temperature and precipitation followed the same procedure, as used in terms of elevation. This process was based on the results of the low altitudinal site only, because at the high altitude there were no significant differences among provenances at age 36 months (Table 2), nor was the altitudinal trend significant (Figure $3 b$ ).

These zones are to be used for guiding seed and seedling transfer through selection of the best seed source according to the objectives of reforestation prac-

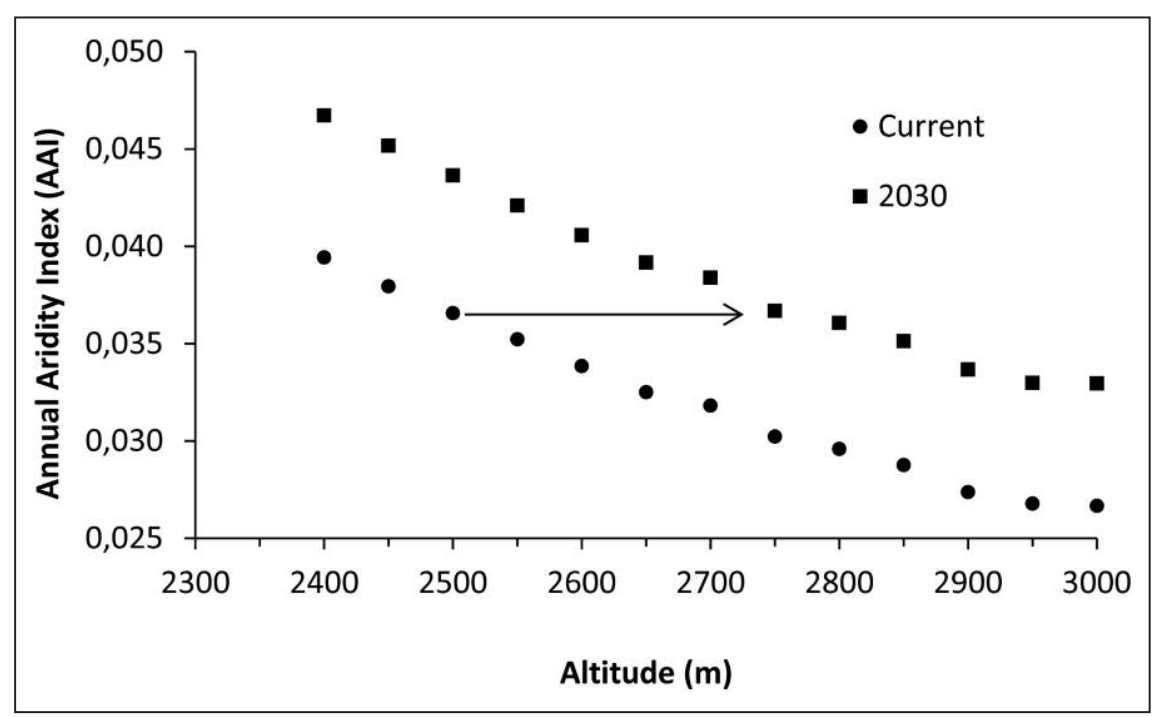

Figure 5. - Average annual aridity index (AAI, larger values are dryer and warmer) for contemporary (average 1961-1990, circle symbols) and future climate projections (decade centered in the year 2030; average across six model-scenario; square symbols), for 13 Pinus patula provenances along an altitudinal cline. The arrow shows the altitude shift required (approximately 200 to $250 \mathrm{~m}$ ) to match contemporary AAI in 2030 for the provenance originating at $2550 \mathrm{~m}$ of altitude, as an example. 
tices for: (a) Ecological restoration and conservation of genetic resources, in which case the guideline is to use seed or seedlings originating within the same seed zone or within $\pm 100 \mathrm{~m}$ in altitude of the seed source; (b) tree breeding for wood production in commercial plantations, in which the guideline is to select sources from the best growing provenance or populations within the seed zone with the best growth performance; and (c) adaptation to climatic change effects, in which the guideline is to collect seeds from a given seed zone, produce seedlings in the nursery and plant in the adjacent altitudinal zone, higher than the current zone. In terms of the ability of $P$. patula populations to cope with the climate projected for the decade centered around 2030, populations should be shifted attitudinally between approximately 200 and $250 \mathrm{~m}$ upwards, to expected similar climatic conditions (AAI) in which populations are currently adapted (Figure 5). Such an upward altitudinal shift is roughly equivalent to the width of a delineated seed zone. Notice that seed zones differ by about $0.004 \mathrm{AAI}, 1.2^{\circ} \mathrm{C}$ in mean annual temperature and 88 mm precipitation (Table 5), and that estimates for 2030 show an AAI increase of 0.006 , mean annual temperature of $1.5^{\circ} \mathrm{C}$ and a decrease in precipitation of approximately $120 \mathrm{~mm}$. Thus, a simplified guide for field management, in at least partially coping with these projected climatic change, would be to collect seeds from a given seed zone, produce seedlings in the nursery and plant in the adjacent altitudinal zone, higher than the current zone.

\section{Discussion}

The altitudinal pattern of differentiated growth among populations of $P$. patula is likely to be the result of local adaptation to environmental conditions. Environmental differences along the altitudinal gradient, even over short linear distances, are a characteristic of steep landscapes and typically generate genetic variation in populations distributed along the gradient, in response to differential selection pressures (THOMAS, 2011; Mori et al., 2013).

In this study, $P$. patula populations originating, in general, at mid-low and mid altitudes had a higher growth potential, which seems to be characteristic of this species (SALAZAR-García, 1999). However, the population from the extreme lowest altitude $(2400 \mathrm{~m})$ had poorer growth performance than other populations from similar altitudes. This is possibly due to the accepted strategy for pine populations from low altitudes, tending to have a more conservative growth strategy to avoid drought stress (SÁENZ-Romero et al., 2006). At its low altitudinal limit, $P$. patula is interspersed with $P$. oaxacana, a species that grows in much dryer sites than $P$. patula. On the opposite altitudinal extreme, provenances from upper altitudes and colder climates, in general grew slower, since they may have evolved strategies to survive adverse conditions of lower winter temperatures, through shorter growing seasons and extended and deeper dormancy periods, than those sourced from warmer climates (DvorAK et al., 2000; SÁENZ-ROMERo et al., 2006; MitCHELL et al., 2013).
The consistency of the best performing provenance, from altitude $2650 \mathrm{~m}$, is remarkable. It was further one of the best performing provenances at the nursery stage (SÁEnz-Romero et al., 2011b), as well as in growth chambers (SÁENZ-Romero et al., 2011a).

\section{Management alternatives of altitudinal zoning}

The proposed seed zones may be used for several practical applications in reforestation and forest management programs.

In ecological restoration programs, the main objective is to restore a transformed area with original elements and functions (HoBBs and NorTon, 1996). Thus, seed collected within a zone can then be used within the same zone, on the assumption that these are well adapted to local environmental conditions (ST. CLAIR, 2006; Gonzalo-TurPin and HAZARD, 2009). Similar rules apply for programs focused on conservation of forest genetic resources, where in-situ protection is vital for protecting the genetic diversity, as well as allowing the natural evolutionary forces to shape the genetic structure of populations. For genetic conservation, reforestation should capture a representative sample of the genetic diversity of $P$. patula within the zone (DvorAK et al., 2000).

In tree breeding for commercial timber production, it is advisable to select the population with greater performance in both sites, or use the zone with the best population. Hence, the population originating at $2650 \mathrm{~m}$ would be the ideal source, due to its superior seedling height exhibited at both sites, up to age 36 months. The results of the combined and individual site analyses suggest that these provenances are likely to perform successfully at any place along the cline, within the natural distribution.

\section{Adapting to the effects of climatic change}

In order to prevent the negative effects of poor adaptation of $P$. patula populations to future global warming scenarios, we suggest following the zoning guidelines, by initially moving upwards in the slope $200 \mathrm{~m}$ from the collection site, sufficient to achieve or at least approach the estimated climate requirements for adaptation to 2030. Shifting seed sources $200 \mathrm{~m}$ upwards to a colder climate, allows populations from warmer climates to adapt and grow more than local seed sources (Schmidtling, 1994). In nature, populations are likely to reduce the differences between optimum and occupied climate by inhabiting environments colder than ideal (REHFELDT et al., 2002). However, an excessive upward altitudinal shift, such as expected by migrating populations in adapting to projected climates in the more distant future, such as the decades centered in the years 2060 or 2090, would increase the risk of frost damage (SÁENZ-Romero and TAPIA-OlIVARES, 2008).

Gene exchange between assisted migrated populations and surrounding local populations would be expected, considering the wide gene flow of an open pollinated species such as this. The resulting next generation of such gene exchange might have on average an intermediate performance between the local and the planted, as 
well as a large genetic variation that might serve as a wide array of genotypes to be selected under future climatic conditions, which would have a positive effect (KREMER et al., 2012).

The proposed zonification ideally should be confirmed for additional tests from seed collected along altitudinal gradients from other regions of the $P$. patula distribution (states of Tamaulipas, Veracruz, Hidalgo, Querétaro and Puebla).

\section{Conclusions}

There is genetic differentiation among populations of Pinus patula for seedling growth in terms of seedling height. The altitudinal pattern demonstrated that mid and low provenances performed better than populations from higher altitudes. The provenance from $2650 \mathrm{~m}$ showed the best growth and could be preliminarily selected as a source of seed for commercial plantations of this species, in the region of this study. Based on the altitudinal difference that causes any two populations to differ genetically, we propose an altitudinal and climate zoning, for decision-making in regard to management of seed and seedlings of $P$. patula for reforestation purposes in Ixtlán de Juárez, Oaxaca. Our suggested seed zoning should have the following altitudinal limits: Zone 1, from 2300 to $2500 \mathrm{~m}$; Zone 2, from 2500 to $2700 \mathrm{~m}$; Zone 3, from 2700 to 2900; and Zone 4, from 2900 to $3100 \mathrm{~m}$. Those limits have their climatic equivalence in mean annual temperature, mean annual precipitation and in annual aridity index (ratio of square root of degree days to mean annual precipitation). For management of natural resources for adaptation to climate change, we suggest an attitudinal upward shift of the seed sources, of maximum range of $200 \mathrm{~m}$ from the collection site.

\section{Acknowledgements}

Financial support was provided to CSR by the joint Forestry Research Fund of the Mexican Council of Science and Technology (CONACYT) and the Mexican National Forestry Commission (CONAFOR, Grant 2005-C02-14783), the Coordinación de la Investigación Cientifica of the Universidad Michoacana de San Nicolás de Hidalgo (UMSNH) and a Graduate Studies Fellowship for LFRT from CONACYT (Fellowship 17572). Seed collection, seedling nursery production and field test maintenance was made possible, thanks to Antonio Plancarte, Julio Ruiz, Samuel Ramírez, Mauro Aquino, Mayolo Ruiz, Eduardo Aquino and others from the Forestry Office of the Native Indian Community of Ixtlán de Juárez, Oaxaca and seed extraction by Rodrigo Niniz at UMSNH. We thank XAVIER MADRIGAL-SÁNCHEZ for valuable comments regarding the ecology of the species and ALEJANDRO MARTíNEZ-PALACIOS for reviewing an early manuscript. Comments of two anonymous reviewers greatly improved the manuscript. We would like to thank RICHARD SCHERLOWSKI and RICHARD BENJAMIN for their assistance with English editing of the manuscript and to Consuelo MARIN-Togo for making the map.

\section{References}

Aitken, S. N., S. Yeaman, J. A. Holliday, T. Wang and S. CURTIS-MCLANE (2008): Adaptation, migration or extirpation: climate change outcomes for tree populations. Evolutionary Applications 1(1): 95-111.

Carrasquinho, I. and E. Gonçalves (2013): Genetic variability among Pinus pinea L. provenances for survival and growth traits in Portugal. Tree Genetics \& Genomes 9(3): 855-866.

Castellanos-Bolaños, J. F., E. J. T. Garza, Ó. A. A. Calderón, J. J. Pérez, M. Musalem-Santiago and R. LóPEZ-AGUiLlón (2008): Estructura de bosques de pino pátula bajo manejo en Ixtlán de Juárez, Oaxaca, México. Madera y Bosques 14(2): 51-63.

Castellanos-Acuña, D., R. A. Lindig-Cisneros, M. A. Silva-FARIAS and C. SÁENZ-Romero (2014): Provisional altitudinal zoning of Abies religiosa in an area near the Monarch Butterfly Biosphere Reserve, Michoacán. Revista Chapingo Serie Ciencias Forestales y del Ambiente 20(2): 215-225.

Crookston, N. L. and Rehfeldt, G. E. (2013): Research on Forest Climate Change: Potential Effects of Global Warming on Forests and Plant Climate Relationships in Western North America and Mexico in 'http:// forest.moscowfsl.wsu.edu/climate/'. USDA Forest Service,USA.

Dvorak, W., G. Hodge, J. Kietzka, F. Malan, L. Osorio and T. Stanger (2000): Pinus patula. In: 'Conservation and testing of tropical and subtropical forest tree species'. pp. 148-173. CAMCORE Cooperative, USA.

Dvorak, W. S., G. R. Hodge and K. G. Payn (2008): The conservation and breeding of Eucalyptus urophylla: a case study to better protect important populations and improve productivity. Southern Forests: a Journal of Forest Science 70(2): 77-85.

Gonzalo-Turpin, H. and L. HAzARD (2009): Local adaptation occurs along altitudinal gradient despite the existence of gene flow in the alpine plant species Festuca eskia. Journal of Ecology 97(4): 742-751.

HobBs, R. J. and D. A. NorTon (1996): Towards a conceptual framework for restoration ecology. Restoration Ecology 4: 93-110.

IPCC Intergovernmental Panel on Climate Change (2013): 'http://www.ipcc.ch'.

Johnstone, J. F. and F. S. CHAPIN (2003): Non-equilibrium succession dynamics indicate continued northern migration of lodgepole pine. Global Change Biology 9(10): 1401-1409.

Jump, A. S., C. MÁtyás and J. PeÑuelas (2009): The altitude-for-latitude disparity in the range retractions of woody species. Trends in Ecology \& Evolution 24(12): 694-701.

MATSUZAKI, K. and B. Y. L. Wong (2010): Forest management through community-based forest enterprises in Ixtlan de Juarez, Oaxaca, Mexico in 'http://satoyamainitiative.org/en/case_studies-2/area_americas-2/forestmanagement-through-community-based-forest-enterprises-in-ixtlan-de-juarez-oaxaca-mexico/. Inited Nations University, Institute of Advanced Studies.

KARIUKI, J. G. (1998): Provenance and family-withinprovenance variation in Pinus patula, Pinus patula subspecies tecunumanii and Pinus oocarpa planted at Turbo, Kenya. Forest Ecology and Management 107(1-3): 127-133. 
Kremer, A., O. Ronce, J. J. Robledo-Arnuncio, F. GuILlaume, G. Bohrer, R. Nathan, J. R. Bridle, R. Gomulkiewicz, E. K. Klein, K. Ritland, A. Kuparinen, S. Gerber and S. Schueler (2012): Long-distance gene flow and adaptation of forest trees to rapid climate change. Ecology Letters 15(4), 378-392

Lenoir, J., J. C. GÉgout, P. A. Marquet, P. De Ruffray and H. BRISSE (2008): A Significant upward shift in plant species optimum elevation during the $20^{\text {th }}$ century. Science 320(5884): 1768-1771.

Louw, J. H. and M. C. Scholes (2006): Site index functions using site descriptors for Pinus patula plantations in South Africa. Forest Ecology and Management 225(1-3): 94-103.

Loya-Rebollar, E., C. SÁenz-Romero, R. A. LindigCisneros, P. Lobit, J. A. Villegas-Moreno and N. M. SÁNCHEZ-VARGAS (2013): Clinal variation in Pinus hartwegii populations and its application for adaptation to climate change. Silvae Genetica 62(3): 86-95.

MÁTYÁs, C. (1994): Modeling climate change effects with provenance test data. Tree Physiology 14(7-8-9): 797-804.

MÁTYÁs, C. (2010): Forecasts needed for retreating forests. Nature 464(7293): 1271.

Mátyás, C., I. Berki, B. Czúcz, B. Gálos, N. Móricz and E. RAszTovits (2010): Future of beech in Southeast Europe from the perspective of evolutionary ecology. Acta Silvatica \& Lignaria Hungarica 6(91-110).

McLachlan, J. S., J. J. Hellmann and M. W. Schwartz (2007): A framework for debate of assisted migration in an era of climate change. Conservation Biology 21(2): 297-302.

Mitchell, R. G., M. J. Wingfield, G. R. Hodge, W. S. DvoraK and T. A. Coutinho (2013): Susceptibility of provenances and families of Pinus maximinoi and Pinus tecunumanii to frost in South Africa. New Forests 44(1): 135-146.

Mori, A. S., T. Shiono, D. Koide, R. Kitagawa, A. T. Ota and E. Mizumachi (2013): Community assembly processes shape an altitudinal gradient of forest biodiversity. Global Ecology and Biogeography 22(7): 878-888.

Oviedo, G. (2002): Forest Management and Protected Areas by the Union of Zapotec-Chinantec Communities of Oaxaca in 'The Community Protected Natural Areas in the State of Oaxaca, Mexico'. World Wildlife Fund (WWF), Gland, Switzerland. pp 29-32.

Peñuelas, J., R. OGaya, M. BoadA and A. S. Jump (2007): Migration, invasion and decline: changes in recruitment and forest structure in a warming-linked shift of European beech forest in Catalonia (NE Spain). Ecography 30(6): 829-837.

Perry, J. P. J. (1991): The Pines of Mexico and Central America. Timber Press, Portland, OR, USA.

REHFELDT, G. E. (1991): A model of genetic variation for Pinus ponderosa in the Inland Northwest (U.S.A.): applications in gene resource management. Canadian Journal of Forest Research 21(10): 1491-1500.

REHFELDT, G. E. (1995): Genetic variation, climate models and the ecological genetics of Larix occidentalis. Forest Ecology and Management 78(1-3): 21-37.

Rehfeldt, G. E., N. M. Tchebakova, Y. I. Parfenova, W. R. Wykoff, N. A. Kuzmina and L. I. Milyutin (2002): Intraspecific responses to climate in Pinus sylvestris. Global Change Biology 8(9): 912-929.
REHFELDT, G. E. (2006): A spline model of climate for the western United States. US Department of Agriculture, Forest Service, Rocky Mountain Research Station Ft. Collins, Colorado, USA,

Rehfeldt, G. E., N. L. Crookston, M. V. Warwell and J. S. Evans (2006): Empirical analyses of plant climate relationships for the Western United States. International Journal of Plant Sciences 167(6): 1123-1150.

REHFELDT, G. E and B. JAQUISH (2010): Ecological impacts and management strategies for western larch in the face of climate-change. Mitig Adapt Strat Glob Change 15(3): 283-306.

Rehfeldt, G. E., N. L. Crookston, C. SÁenz-Romero and E. M. CAMPBELL (2012): North American vegetation model for land-use planning in a changing climate: a solution to large classification problems. Ecological Applications 22(1): 119-141.

RehFELdT, G. E., B. C. JAquish, J. López-Upton, C. SÁenzRomero, J. B. StClair, L. P. Leites and D. G. Joyce (2014): Comparative genetic responses to climate for the varieties of Pinus ponderosa and Pseudotsuga menziesii: Realized climate niches. Forest Ecology and Management 324: 126-137.

SÁenz-Romero, C., R. R. Guzmán-Reyna and G. E. REHFELDT (2006): Altitudinal genetic variation among Pinus oocarpa populations in Michoacán, Mexico: Implications for seed zoning, conservation, tree breeding and global warming. Forest Ecology and Management 229(1-3): 340-350.

SÁenz-Romero, C. and B. TAPIA-Olivares (2008): Genetic variation in frost damage and seed zone delineation within an altitudinal transect of Pinus devoniana (P. michoacana) in Mexico. Silvae Genetica 57(3): 165.

Sáenz-Romero, C., G. E. Rehfeldt, N. L. Crookston, P. Duval, R. St-amant, J. Beaulieu and B. A. Richardson (2010): Spline models of contemporary, 2030, 2060 and 2090 climates for Mexico and their use in understanding climate-change impacts on the vegetation. Climatic Change 102(3-4): 595-623.

Sáenz-Romero, C., G. E. Rehfeldt and J. Beaulieu (2011a): Altitudinal genetic variation among Pinus patula populations from Oaxaca, Mexico, in growth chambers simulating global warming temperatures. Agrociencia 45(3): 399-411.

Sáenz-Romero, C., L. Ruiz-Talonia, J. Beaulieu, N. SÁNCHEZ-VARGAS and G. REHFELDT (2011b): Genetic variation among Pinus patula populations along an altitudinal gradient. Two environment nursery tests. Revista Fitotecnia Mexicana 34(1): 6.

Sáenz-Romero, C., G. E. Rehfeldt, P. Duval and R. A. LINDIG-CISNERos (2012a): Abies religiosa habitat prediction in climatic change scenarios and implications for monarch butterfly conservation in Mexico. Forest Ecology and Management 275: 98-106.

Sáenz-Romero, C., G. E. Rehfeldt, J. C. Soto-Correa, S. Aguilar-Aguilar, V. ZamarRIPA-Morales and J. LÓPEZ-UPTON (2012b): Altitudinal genetic variation among Pinus pseudostrobus populations from Michoacán, México. Two locations shadehouse test results. Revista Fitotecnia Mexicana 35(2): 111-121.

SAlazar-García, J. G., J. J. VARGas-HernándeZ, J. D. JASSO-MATA, C. RAMíREZ-HERRERA and J. LÓPEZ-UPTON (1999): Variación en el patrón de crecimiento en altura de cuatro especies de Pinus en edades tempranas. Madera y Bosques 5(2): 19-34. 